\title{
Type 2 Diabetes In Urban and Rural Areas: A Comparative Study
}

\author{
Diabetes Tipe 2 di Wilayah Perkotaan dan Pedesaan: Studi Komparasi
}

\author{
Emmi Bujawati*1, Rahmi Awaliah², Jumriani Ansar ${ }^{3}$ \\ ${ }^{1,2}$ Bagian Kesehatan Masyarakat, Universitas Islam Negeri Alauddin Makassar, Makassar \\ ${ }^{3}$ Bagian Kesehatan Masyarakat, Universitas Hasanuddin, Makassar
}

DOI: 10.24252 /al-sihah.v13i2.25884

Received: 21 December 2021 / In Reviewed: 22 December 2021 / Accepted: 26 December 2021 / Available online: 30 December 2021 (C) The Authors 2021. This is an open access article under the CC BY-NC-SA 4.0 license

\begin{abstract}
Diabetes mellitus type 2 is one of the degenerative diseases whose mortality and morbidity rates continue to increase, both in urban and rural areas. Bulukumba Regency is one of the areas with the highest prevalence of type 2 diabetes mellitus. This study aimed to determine the differences in the determinants of the incidence of type 2 diabetes mellitus in urban and rural areas of the Bulukumba Regency in 2021. The type of research used is quantitative with an observational analytic approach and a cross-sectional study design. The population in this study were all people with type 2 diabetes mellitus in urban and rural areas of the Bulukumba Regency. The sample of this study amounted to 210 respondents consisting of 140 respondents in urban areas and 70 respondents in rural areas who were taken using purposive sampling technique with inclusion criteria, namely patients who do not have comorbidities or complications such as coronary heart disease, stroke, and kidney failure as well as patients who are not pregnant at the time of this study. Data were analyzed using the chi-square test. The results of this study indicate that there are differences in consumption of sugar-sweetened beverages $(p=0.032)$, consumption of fast food $(p=0.044)$, physical activity $(p=0.001)$, and economic status $(p=0.04)$ of people with type 2 diabetes mellitus in urban and rural areas. Meanwhile, there was no difference in smoking behavior $(p=0.404)$ with type 2 diabetes mellitus in urban and rural areas of the Bulukumba Regency. Management of type 2 diabetes mellitus is important as early as possible so that the morbidity rate due to diabetes can be reduced in the future. The different risk factors between urban and rural areas should be taken into account
\end{abstract}

\section{ABSTRAK}

Diabetes mellitus tipe 2 termasuk salah satu penyakit degeneratif yang angka mortalitas dan morbiditas yang terus meningkat, baik di wilayah perkotaan maupun pedesaan. Kabupaten Bulukumba merupakan salah satu daerah dengan prevalensi penderita diabetes mellitus tipe 2 terbanyak. Penelitian ini bertujuan untuk mengetahui perbedaan determinan kejadian diabetes mellitus tipe 2 di wilayah perkotaan dan pedesaan Kabupaten Bulukumba tahun 2021. Jenis penelitian yang digunakan adalah kuantitatif dengan pendekatan analitik observasional dan desain cross sectional study. Populasi dalam penelitian ini adalah seluruh penderita diabetes mellitus tipe 2 yang ada di wilayah perkotaan dan wilayah pedesaan Kabupaten Bulukumba. Sampel penelitian ini berjumlah 210 responden yang terdiri atas 140 responden di wilayah perkotaan dan 70 responden di wilayah pedesaan yang diambil menggunakan teknik purposive sampling dengan kriteria inklusi yaitu penderita yang tidak memiliki penyakit penyerta atau komplikasi seperti penyakit jantung koroner, stroke, dan gagal ginjal serta penderita yang tidak dalam keadaan hamil pada saat penelitian ini dilaksanakan. Data dianalisis dengan menggunakan uji chi-square. Hasil penelitian ini menunjukkan bahwa terdapat perbedaan konsumsi minuman manis $(\mathrm{p}=0,032)$, konsumsi makanan cepat saji $(\mathrm{p}=0,044)$, aktivitas fisik $(p=0,001)$ dan status ekonomi $(p=0,04)$ penderita diabetes mellitus tipe 2 di wilayah perkotaan dan pedesaan. Sedangkan tidak terdapat perbedaan perilaku merokok $(\mathrm{p}=0,404)$ penderita diabetes mellitus tipe 2 di wilayah perkotaan dan pedesaan Kabupaten Bulukumba. Penanggulangan diabetes mellitus tipe 2 penting dilakukan sedini mungkin agar angka morbiditas akibat diabetes dapat berkurang di masa mendatang. Faktor risiko yang berbeda antara wilayah perkotaan dan pedesaan hendaknya menjadi pertimbangan.

\section{GRAPHICAL ABSTRACT}

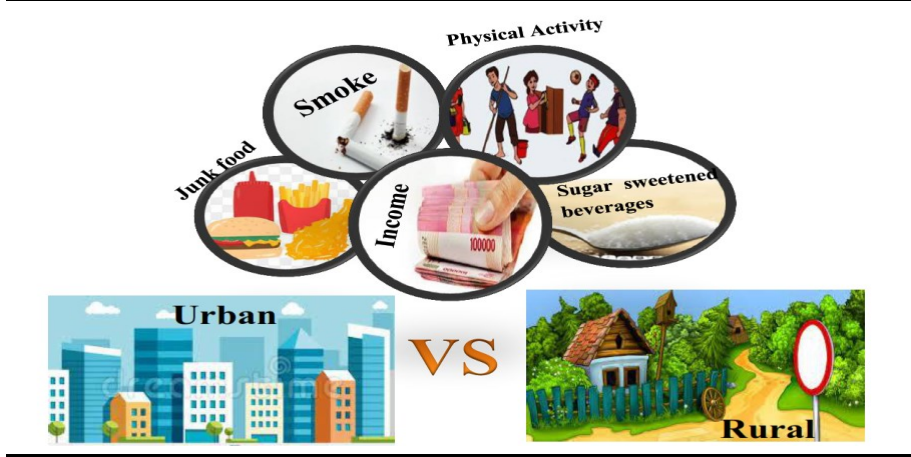

Keyword

comparative study; determinant of diabetes; diabetes mellitus type 2; rural and urban

Kata Kunci:

determinan diabetes; diabetes mellitus tipe 2; perkotaan dan pedesaan; studi komparasi

* Correspondence

Perumahan Ilma D'mansion Blok C20 Antang,

Kota Makassar

Email: emmi.bujawati@uin-alauddin.ac.id 


\section{PENDAHULUAN}

Diabetes mellitus termasuk salah satu penyakit degeneratif dengan angka mortalitas dan morbiditas yang terus meningkat secara global, baik di negara industri maupun negara berkembang (Azis et al., 2020). World Health Organization (2019)menyatakan setiap tahunnya penyakit diabetes menyebabkan 1,6 juta kematian dan merupakan penyebab kematian kesembilan, dengan $80 \%$ kasus kematian berasal dari negara berpenghasilan rendah dan menengah. Penyakit diabetes telah menjadi tantangan kesehatan yang berkembang paling cepat di abad 21 dan dalam 20 tahun terakhir jumlah orang dewasa yang hidup dengan diabetes meningkat lebih dari tiga kali lipat. Pada tahun 2019 jumlah penderita diabetes mencapai 463 juta pada usia 20-79 tahun dengan 232 juta jiwa tidak sadar bahwa mengidap penyakit diabetes mellitus. Estimasi pada tahun 2030 jumlah penderita diabetes mencapai 578 juta orang dewasa dan meningkat menjadi 700 juta pada tahun 2045 (International Diabetes Federation, 2019). American Diabetes Association (2019) juga melaporkan bahwa dalam 21 detik akan ada satu orang yang menderita diabetes di dunia.

Penyakit diabetes mellitus diklasifikasi menjadi diabetes mellitus tipe I, diabetes mellitus tipe II, diabetes mellitus tipe gestasional dan tipe lainnya. Diabetes mellitus tipe 2 (DMT2) merupakan tipe diabetes yang paling sering di derita oleh masyarakat dan menjadi penyumbang sekitar 90\% 95\% penderita diabetes mellitus di seluruh populasi (Adri et al., 2020). International Diabetes Federation menyebutkan bahwa penderita diabetes mellitus Tipe 2 mencapai 415 juta di tahun 2015 dan angka ini diperkirakan terus meningkat menjadi 642 juta di tahun 2040 (International Diabetes Federation, 2019). Lebih dari setengah populasi diabetes dunia berada di Asia terutama India, China, Pakistan, dan Indonesia (Yosmar et al., 2018).

Indonesia termasuk salah satu negara berkembang dengan angka kejadian diabetes mellitus tipe 2 yang cukup tinggi dan menjadi peringkat ketujuh di Asia Tenggara. Hasil Riset Kesehatan Dasar yang dilaporkan oleh Kementerian Kesehatan RI (2018) menunjukkan prevalensi diabetes mellitus berdasarkan diagnosis dokter meningkat dari 1,5\% pada tahun 2013 menjadi 2\% pada tahun 2018. Dengan prevalensi diabetes mellitus terbanyak di wilayah perkotaan sebanyak $1,89 \%$ atau 556,419 jiwa dan wilayah pedesaan sebanyak 1,01\% atau 460,871 jiwa. Kelompok umur yang paling tinggi prevalensinya adalah 55-64 tahun $(6,29 \%)$ dan prevalensi jenis kelamin perempuan $(1,78 \%)$ lebih tinggi dari lakilaki (1,21\%). Dari data tersebut dapat disimpulkan bahwa penyakit diabetes mellitus di Indonesia masih menjadi masalah kesehatan yang cukup serius dan memerlukan tindakan dari berbagai pihak. Jika tidak segera diatasi, situasi ini dapat memberikan dampak yang merugikan dan mengakibatkan penurunan produktivitas (Pawaskar et al., 2018), mengurangi usia harapan hidup (Walker et al., 2018), kecacatan (Quiñones et al., 2019), bahkan kematian dini (Lewis et al., 2019).

Sulawesi Selatan termasuk salah satu provinsi yang memiliki prevalensi diabe- 
tes terbanyak. Berdasarkan diagnosis dokter pada penduduk semua umur penderita diabetes sebanyak 1,3\% atau 33.693 jiwa, sedangkan pada penduduk umur $\geq 15$ tahun sebanyak 1,8\% atau 23.069 jiwa (Kementerian Kesehatan RI, 2018). Data Dinas Kesehatan Sulawesi Selatan (2019) juga melaporkan bahwa kejadian diabetes mellitus di tahun 2019 mencapai 143.311 kasus dan menduduki peringkat kedua penyakit tidak menular setelah hipertensi. Salah satu daerah di Sulawesi Selatan yang mempunyai penderita diabetes terbanyak adalah Kabupaten Bulukumba.

Prevalensi kasus diabetes yang terus meningkat setiap tahunnya baik di wilayah perkotaan dan pedesaan di Kabupaten Bulukumba menunjukkan bahwa diabetes mellitus merupakan masalah kesehatan yang harus dikendalikan. Berdasarkan laporan kepala Dinas Kesehatan Kabupaten Bulukumba tahun 2020 diabetes termasuk masalah kesehatan prioritas selain hipertensi. Kasus diabetes tahun 2018 mencapai 5.520 kasus dan meningkat menjadi 8.121 kasus di tahun 2019 dan menjadi 10.551 kasus di tahun 2020. Puskesmas Caile merupakan puskesmas dengan kasus diabetes tertinggi di wilayah perkotaan yaitu sebanyak 1.355 orang pada tahun 2019 dan meningkat menjadi 1.500 orang pada tahun 2020 dengan jumlah penderita diabetes mellitus tipe 2 sebanyak 210 orang. Sedangkan di wilayah pedesaan yaitu Puskesmas Tanete dengan jumlah penderita 220 orang di tahun 2019 dan meningkat menjadi 275 di tahun 2020 dengan 100 orang diantaranya diagnosis diabetes tipe 2 .

Tingginya prevalensi diabetes yang terjadi baik di wilayah perkotaan maupun pedesaan memerlukan pengendalian dan penanganan yang cepat dan tepat . Perbedaan perilaku dan paparan faktor risiko memberikan kontribusi terhadap perbedaan prevalensi kejadian DM atau prognosis komplikasi pada penderita DM di kota dan di desa. Penderita diabetes mellitus tipe 2 yang tidak tertangani dengan baik dapat menyebabkan komplikasi seperti penyakit jantung (Pencina et al., 2019), gagal ginjal (Bhatt et al., 2021), stroke (Tun et al., 2017), dan memperparah penyakit yang telah diderita.

Untuk mencegah terjadi komplikasi pada penderita diabetes maka perlu dilakukan tindakan pengendalian faktor risiko. Beberapa faktor risiko yang mempengaruhi terjadinya diabetes mellitus tipe 2 telah dibuktikan oleh beberapa peneliti memiliki korelasi. Hirahatake et al. (2019) serta Papier et al. (2017) membuktikan bahwa faktor gaya hidup seperti pola makan yang tidak sehat meliputi konsumsi sugarsweetened beverages dapat mempengaruhi risiko terjadinya diabetes. Selain itu Alsabieh et al. (2019) yang menghubungkannya dengan kebiasaan mengkonsumsi makanan cepat saji, Radzeviciene \& Ostrauskas (2018) yang mengkorelasikan dengan kebiasaan merokok, serta Nomura et al. (2018) karena aktivitas fisik yang kurang. Pengendalian berbagai penyakit dapat dilakukan dengan mengendalikan faktor risiko yang ada dan diderita oleh penduduk baik perkotaan maupun pedesaan. Pola hidup masyarakat desa dan kota yang berbeda dapat mempengaruhi perbedaan timbulnya jumlah kasus penyakit akibat gaya 
hidup. Beberapa peneliti telah mengkaji perbedaan penyakit komorbid di wilayah perkotaan dan pedesaan. Seperti Kapral et al. (2019) yang meneliti mengenai stroke, $\mathrm{Ba}$ et al. (2018) mengenai hipertensi, serta Oommen et al. (2016) mengenai penyakit jantung koroner. Oleh karena itu, peneliti ingin melengkapi kajian mengenai kasus penyakit diabetes mellitus di dua wilayah berbeda. Penelitian ini bertujuan untuk mengetahui perbandingan determinan kejadian diabetes mellitus tipe 2 di wilayah perkotaan dan pedesaan sehingga dapat dilakukan upaya pencegahan dan pengendalian yang lebih baik lagi.

\section{METODE PENELITIAN}

Penelitian ini merupakan penelitian kuantitatif dengan pendekatan analitik observasional dan desain cross sectional study. Populasi dalam penelitian ini adalah seluruh penderita diabetes mellitus tipe 2 yang ada di wilayah perkotaan dan wilayah pedesaan Kabupaten Bulukumba. Sampel penelitian ini berjumlah 210 responden yang terdiri atas 140 responden di wilayah perkotaan dan 70 responden di wilayah pedesaan yang diambil menggunakan teknik purposive sampling dengan kriteria inklusi yaitu penderita yang tidak memiliki penyakit penyerta atau komplikasi seperti penyakit jantung koroner, stroke, dan gagal ginjal serta penderita yang tidak dalam keadaan hamil pada saat penelitian ini dilaksanakan.

Penelitian ini dilakukan pada bulan Juli-September 2021 dan telah mendapatkan izin laik etik no. B093/KEPK/FKIK/ VII/2021. Data yang dikumpulkan berupa karakteristik responden, konsumsi SSBs, konsumsi makanan cepat saji, aktivitas fisik, perilaku merokok dan status ekonomi penderita diabetes. Seluruh responden dalam penelitian ini menandatangani informed consent sebagai bukti kesediaan terlibat sebagai subjek sukarela penelitian. Data primer dalam penelitian ini dikumpulkan dengan menggunakan instrumen kuesioner dan teknik wawancara langsung. Data kemudian dianalisis menggunakan uji chisquare pada aplikasi SPSS versi 16.

\section{HASIL PENELITIAN}

Hasil analisis karakteristik responden (Tabel 1) menunjukkan bahwa mayoritas responden berjenis kelamin perempuan di wilayah perkotaan dan pedesaan yaitu 82 responden $(58,6 \%)$ dan 44 responden $(62,9 \%)$. Mayoritas umur responden yaitu lansia awal (45-55 tahun) di wilayah perkotaan dan pedesaan sebanyak 66 responden $(47,1 \%)$ dan 32 responden (45,7\%). Mayoritas Responden bekerja sebagai IRT sebanyak 47 responden $(33 \%)$ di wilayah perkotaan dan 26 responden $(37,1 \%)$ di wilayah pedesaan. Tingkat pendidikan paling banyak di wilayah perkotaan adalah Tamat PT sebanyak 38 responden $(27,1 \%)$ sedangkan di wilayah pedesaan Tamat SMA/MA/SMK sebanyak 27 responden $(38,6 \%)$. Dan mayoritas responden tidak memiliki riwayat keluarga diabetes sebanyak 94 responden $(67,1 \%)$ di wilayah perkotaan dan 56 responden $(80 \%)$ di wilayah pedesaan.

Hasil analisis Bivariat (Tabel 2) menunjukkan bahwa terdapat perbedaan konsumsi sugar-sweetened beverages $(\mathrm{P}=$ 0,032), pola konsumsi makanan cepat saji 
Tabel 1

Distribusi Karakteristik Responden

\begin{tabular}{|c|c|c|c|c|}
\hline \multirow{2}{*}{ Karakteristik Responden } & \multicolumn{2}{|c|}{ Perkotaan $(n=140)$} & \multicolumn{2}{|c|}{ Pedesaan $(n=70)$} \\
\hline & $\mathrm{n}$ & $\%$ & $\mathrm{n}$ & $\%$ \\
\hline \multicolumn{5}{|l|}{ Jenis Kelamin } \\
\hline Laki-laki & 58 & 41,4 & 26 & 37,1 \\
\hline Perempuan & 82 & 58,6 & 44 & 62,9 \\
\hline \multicolumn{5}{|l|}{ Umur } \\
\hline Dewasa Awal (33-35 tahun) & 3 & 2,1 & 2 & 2,9 \\
\hline Dewasa Akhir(36-45 tahun) & 25 & 17,8 & 14 & 20 \\
\hline Lansia Awal (46-55 tahun) & 66 & 47,1 & 32 & 45,7 \\
\hline Lansia Akhir (56-65 tahun) & 46 & 32,8 & 18 & 25,7 \\
\hline Manula $(>65)$ & 0 & 0 & 4 & 5,7 \\
\hline \multicolumn{5}{|l|}{ Pekerjaan } \\
\hline IRT & 47 & 33 & 26 & 37,1 \\
\hline PNS/TNI/Polri/BUMN/BUMD & 22 & 15,7 & 6 & 8,5 \\
\hline Wiraswasta & 18 & 12,9 & 6 & 8,5 \\
\hline Petani & 2 & 1,4 & 16 & 22,9 \\
\hline Tidak Bekerja & 8 & 5,7 & 7 & 10 \\
\hline Pensiunan & 12 & 8,6 & 2 & 2,9 \\
\hline Pegawai Swasta & 11 & 7,9 & 3 & 4,3 \\
\hline Buruh/Sopir/Pembantu Ruta & 7 & 5 & 2 & 2,9 \\
\hline Honorer & 7 & 5 & 2 & 2,9 \\
\hline Nelayan & 6 & 4,2 & 0 & 0 \\
\hline \multicolumn{5}{|l|}{ Pendidikan Terakhir } \\
\hline Tidak Sekolah & 5 & 3,6 & 2 & 2,9 \\
\hline Tidak Tamat SD/MI & 3 & 2,1 & 7 & 10 \\
\hline Tamat SD/MI & 21 & 15 & 7 & 10 \\
\hline Tamat SMP/MTS & 23 & 16,4 & 12 & 17,1 \\
\hline Tamat SMA/SMK/MA & 29 & 20,7 & 27 & 38,6 \\
\hline Tamat D1/D2/D3 & 21 & 15 & 2 & 2,9 \\
\hline Tamat PT & 38 & 27,1 & 13 & 18,5 \\
\hline \multicolumn{5}{|l|}{ Riwayat Keluarga/Genetik } \\
\hline Ada & 46 & 32,8 & 14 & 20 \\
\hline Tidak Ada & 94 & 67,2 & 56 & 80 \\
\hline
\end{tabular}

$(\mathrm{P}=0,044)$, Aktivitas fisik $(\mathrm{P}=0,001)$ Status ekonomi $(\mathrm{P}=0.04)$ antara penderita $\mathrm{DM}$ tipe 2 di wilayah perkotaan dan pedesaan dan tidak ditemukan perbedaan pola perilaku merokok $(\mathrm{P}=0,404)$ antara penderita DM tipe 2 di wilayah perkotaan dan pedesaan.

\section{PEMBAHASAN}

\section{Perbedaan Konsumsi Sugar-Sweetened Beverages}

Hasil temuan pada riset ini menunjukkan bahwa mayoritas penderita diabetes mellitus tipe 2 di wilayah perkotaan dan pedesaan sering mengonsumsi sugar sweetened beverages. Dengan proporsi terbanyak pada penderita diabetes di wilayah perkotaan. Hasil analisis lanjut menunjukkan di wilayah pedesaan jenis minuman yang dikonsumsi adalah konsumsi teh ma- 
Tabel 2

Perbedaan Determinan Kejadian Diabetes Mellitus Tipe 2 di Wilayah Perkotaan Dan Pedesaan

\begin{tabular}{|c|c|c|c|c|c|c|c|}
\hline \multirow{3}{*}{ Determinan } & \multicolumn{4}{|c|}{ Diabetes Mellitus Tipe 2} & \multirow{2}{*}{\multicolumn{2}{|c|}{ Total }} & \multirow{3}{*}{ p-value } \\
\hline & \multicolumn{2}{|c|}{ Perkotaan $(n=140)$} & \multicolumn{2}{|c|}{ Pedesaan $(n=70)$} & & & \\
\hline & $\mathrm{n}$ & $\%$ & $\mathrm{n}$ & $\%$ & $\mathrm{n}$ & $\%$ & \\
\hline \multicolumn{8}{|c|}{ Konsumsi Sugar Sweetened } \\
\hline Sering & 94 & 67,1 & 34 & 48,6 & 128 & 61 & \multirow{3}{*}{0,032} \\
\hline Kadang-kadang & 37 & 26,4 & 30 & 42,8 & 67 & 31,9 & \\
\hline Jarang & 9 & 6,5 & 6 & 8,6 & 15 & 7,1 & \\
\hline \multicolumn{8}{|c|}{ Konsumsi Makanan Cepat Saji } \\
\hline Sering & 18 & 12,9 & 4 & 5,7 & 22 & 10,5 & \multirow{3}{*}{0,044} \\
\hline Kadang-kadang & 40 & 28,6 & 13 & 18,6 & 53 & 25,2 & \\
\hline Jarang & 82 & 58,5 & 53 & 75,7 & 135 & 64,3 & \\
\hline \multicolumn{8}{|l|}{ Aktivitas Fisik } \\
\hline Kurang & 54 & 38,6 & 11 & 15,7 & 65 & 31 & \multirow{2}{*}{0,001} \\
\hline Cukup & 86 & 61,4 & 59 & 84,3 & 145 & 69 & \\
\hline \multicolumn{8}{|l|}{ Perilaku Merokok } \\
\hline $\mathrm{Ya}$ & 92 & 65,7 & 50 & 71,4 & 142 & 67,6 & \multirow{2}{*}{0,404} \\
\hline Tidak & 48 & 34,3 & 20 & 28,6 & 68 & 32,4 & \\
\hline \multicolumn{8}{|l|}{ Status Ekonomi } \\
\hline Tinggi & 79 & 56,4 & 29 & 41,4 & 108 & 51,4 & \multirow{2}{*}{0,04} \\
\hline Rendah & 61 & 43,6 & 41 & 58,6 & 102 & 48,6 & \\
\hline
\end{tabular}

nis, kopi dan kopi susu yang dibuat sendiri sedangkan di perkotaan kebanyakan mengkonsumsi minuman kemasan. Hal ini mengindikasikan bahwa masyarakat pedesaan lebih menungkinkan untuk mengatur asupan gula mereka Karena jumlah takaran bisa disesuaikan pada saat membuat teh, kopi atau kopi susu. Berbeda dengan minuman kemasan yang takaran gulanya sudah tidak bisa diubah lagi. Hal yang paling mungkin dilakukan untuk minuman kemasan adalah mengatur jumlah porsi yang dikonsumsi.

Hasil penelitian ini menunjukkan bahwa terdapat perbedaan konsumsi sugar Sweetened beverages penderita diabetes mellitus tipe 2 di wilayah perkotaan dan pedesaan Kabupaten Bulukumba. Hal ini dikarenakan masyarakat perkotaan cenderung tidak hanya mengkonsumsi satu jenis minuman manis, tetapi juga mengkonsumsi minuman manis yang dibeli. Masyarakat perkotaan tidak hanya mengonsumsi minuman manis seperti teh, kopi dan kopi susu yang dibuat sendiri. Akan tetapi masyarakat perkotaan juga sering mengonsumsi minuman manis lainnya seperti minuman rasa buah, minuman berkarbonasi, minuman berenergi, kopi dan teh instan. Berbeda halnya dengan masyarakat pedesaan yang lebih cenderung hanya mengkonsumsi satu jenis minuman manis seperti teh, kopi dan kopi susu.

Hal ini sejalan dengan penelitian yang dilakukan oleh Daeli \& Nurwahyuni (2019) yang mengungkapkan terdapat perbedaan konsumsi minuman manis pada masyarakat pedesaan dan perkotaan. Masyarakat perkotaan diketahui rela mengeluarkan uang lebih banyak untuk 
konsumsi minuman manis dibandingkan masyarakat di pedesaan.

\section{Perbedaan Konsumsi Makanan Cepat Saji}

Hasil penelitian ini mengungkapkan bahwa proporsi penderita diabetes mellitus tipe 2 yang sering mengonsumsi makanan cepat saji lebih banyak pada wilayah perkotaan. Hal ini diduga karena mudahnya akses untuk mendapat makanan cepat saji serta status ekonomi penduduk di wilayah perkotaan relatif tinggi. Berdasarkan hasil tabulasi silang antara konsumsi makanan cepat saji dengan status ekonomi ditemukan bahwa pada status ekonomi yang tinggi, akses terhadap makanan cepat saji pada daerah perkotaan $2 x$ lebih tinggi dibandingkan daerah pedesaan.. Hal ini kemungkinan karena ketersediaan outlet makanan cepat saji lebih banyak dan lebih beragam di kota daripada di desa sehingga peluang masyarakat kota untuk mengakses itu lebih besar daripada masyarakat di desa.

Hasil temuan pada riset ini mengungkapkan terdapat perbedaan konsumsi makanan cepat saji penderita diabetes mellitus tipe 2 di wilayah perkotaan dan pedesaan Kabupaten Bulukumba. Penderita diabetes mellitus tipe 2 di wilayah perkotaan cenderung sering dan kadangkadang mengonsumsi makanan cepat saji. Berbeda halnya dengan penderita diabetes mellitus di wilayah pedesaan yang cenderung jarang mengonsumsi makanan cepat saji. Hal ini diduga dikarenakan perbedaan gaya hidup masyarakat perkotaan yang dikenal berbeda dengan masyarakat pedesaan. Masyarakat perkotaan dikenal menganut gaya hidup yang serba praktis dan sangat menyukai konsumsi makanan cepat saji yang diketahui tergolong makanan berkelas dan dianggap sesuai dengan ciri khas masyarakat perkotaan yang sangat menjunjung tinggi mobilitas. Gaya hidup seperti inilah yang akan memicu risiko serta peningkatan jumlah penderita penyakit diabetes mellitus (Sundufu et al., 2017). Berbeda halnya dengan masyarakat di wilayah pedesaan cenderung jarang mengonsumsi makanan cepat saji dikarenakan karakteristik penduduknya cenderung banyak bergantung pada hasil pertanian sehingga lebih sering mengonsumsi makanan lokal yang diolah sendiri dengan baik serta status ekonomi penduduk di wilayah pedesaan yang relatif rendah.

\section{Perbedaan Aktivitas Fisik}

Penelitian ini menunjukkan bahwa proporsi penderita diabetes mellitus tipe 2 yang kurang melakukan aktivitas fisik di wilayah perkotaan lebih banyak dibandingkan dengan wilayah pedesaan. Hal tersebut diduga karena mayoritas jenis pekerjaan penderita di wilayah perkotaan adalah pekerjaan dengan minim aktivitas gerak seperti pegawai swasta dan ASN. Berbeda halnya dengan masyarakat pedesaan yang mayoritas penduduknya bekerja sebagai petani/buruh tani dimana jenis pekerjaan ini membutuhkan banyak energi atau banyak gerak seperti mencangkul. Selain itu, kebiasaan responden untuk berjalan kaki setiap hari untuk mengunjungi tempat di sekitar rumah baik itu keluarga, tetangga, pasar, atau ladang/sawah mereka, memberikan kontribusi terhadap aktivitas fisik 
mereka. Perbedaan kondisi lingkungan/ kontur geografi antara pedesaan dan perkotaan juga menjadi faktor pendukung tambahan yang berpengaruh pada perbedaan energi yang dikeluarkan oleh masyarakat kota dan desa. Di perkotaan, jarak rumah serta fasilitas publik mudah dijangkau oleh masyarakat sedangkan di pedesaan jarak bangunan cenderung mempunyai jarak antara satu bangunan dengan bangunan lainnya dikarenakan biasanya terdapat lahan perkebunan di antara bangunan tersebut.

Hasil penelitian ini juga menunjukkan bahwa terdapat perbedaan aktivitas fisik antara penderita diabetes mellitus tipe $2 \mathrm{di}$ wilayah perkotaan maupun pedesaan. Mayoritas penderita diabetes mellitus tipe 2 melakukan aktivitas fisik yang cukup. Aktivitas di rumah seperti mencuci, memasak, membersihkan rumah dan berjalan cepat atau naik sepeda ke pasar merupakan aktifitas fisik yang paling sering dilakukan oleh responden sesuai dengan pekerjaannya sebagai ibu rumah tangga (34,7\%). Selain itu keterbatasan fasilitas yang ada di pedesaan mengharuskan seluruh kegiatan tersebut lebih banyak dilakukan secara manual menggunakan tangan. Hal tersebut menjadi faktor yang berpengaruh terhadap perbedaan proporsi aktivitas fisik antara perempuan yang tinggal di wilayah pedesaan $(47,7 \%)$ dengan perempuan perkotaan $(42,4 \%)$.

\section{Perbedaan Perilaku Merokok}

Hasil penelitian ini menunjukkan bahwa sebagian besar responden yang menderita diabetes mellitus tipe 2 di wilayah perkotaan dan pedesaan Kabupaten
Bulukumba adalah perokok dan terpapar asap rokok setiap hari, dengan proporsi terbanyak di pedesaan .Berdasarkan penelitian sebelumnya yang mengemukakan perokok aktif berkaitan dengan peningkatan $44 \%$ penyakit diabetes. Sedangkan perokok pasif berkaitan dengan peningkatan risiko diabetes sebanyak 28\%. Selain itu, dikemukakan bahwa paparan asap rokok pada perokok aktif dan pasif secara positif dan independen berkaitan dengan risiko menderita diabetes mellitus tipe 2 (Pratama et al., 2018).

Hasil penelitian ini menunjukkan bahwa tidak terdapat perbedaan perilaku merokok penderita diabetes mellitus tipe 2 di wilayah perkotaan dan pedesaan $\mathrm{Kabu}-$ paten Bulukumba dengan nilai $p=0,404$ ( $p>0,05)$. Hal tersebut dikarenakan proporsi konsumsi rokok di wilayah pedesaan dan perkotaan tidak jauh berbeda. Meskipun proporsi merokok lebih banyak penderita diabetes mellitus di wilayah pedesaan. Hal ini diduga karena masyarakat daerah pedesaan cenderung mengkonsumsi rokok untuk menghangatkan diri dari hawa dingin. Selain itu, masyarakat di daerah pedesaan cenderung terpapar asap rokok dikarenakan lingkungan tempat tinggal seperti anggota keluarga yang mengkonsumsi rokok didalam rumah dan juga ditempat umum yang dimana wilayah tersebut belum memiliki kawasan tanpa rokok. Berbeda halnya di wilayah perkotaan, dimana telah terdapat kawasan tanpa asap rokok sehingga ada peluang kepada masyarakat untuk tidak terpapar asap rokok. 


\section{Perbedaan Status Ekonomi}

Hasil penelitian menunjukkan bahwa terdapat perbedaan status ekonomi penderita diabetes mellitus tipe 2 di wilayah perkotaan dan pedesaan Kabupaten Bulukumba. Dengan mayoritas penderita diabetes mellitus di wilayah perkotaan berstatus ekonomi tinggi sedangkan mayoritas penderita diabetes mellitus di wilayah pedesaan berstatus ekonomi rendah.

Penelitian yang dilakukan oleh Arda et al. (2020) juga mengungkapkan hal yang sama, kelompok dengan pendapatan yang tinggi lebih rentan terkena diabetes. Hal ini karena sosial ekonomi dan selera makan yang berubah akan mengakibatkan kecenderungan pada masyarakat untuk mengonsumsi makanan praktis dan mudah dijangkau yang status gizinya kurang baik untuk tubuh. Selain itu, ada indikasi bahwa seseorang yang mempunyai pendapatan lebih cenderung lebih konsumtif termasuk dalam mengonsumsi makanan. Konsumsi makanan yang berlebihan yang mengandung kolesterol tinggi dapat berpeluang terdiagnosa menderita diabetes mellitus.Berbeda halnya dengan penelitian yang dilakukan Manuntung (2017), mengungkapkan bahwa seseorang dengan status ekonomi rendah lebih rentan terkena diabetes mellitus tipe 2 dikarenakan tingkat pendapatan rendah akan membuat seseorang cenderung membeli makanan yang tidak mempunyai kandungan gizi yang baik seperti mengkonsumsi mie instan. Sebagai salah satu faktor dalam menentukan tingkat kesejahteraan masyarakat, tingkat pendapatan menduduki peranan yang penting. Taraf hidup seseorang ber- gantung pada tinggi rendahnya penghasilan seseorang. Peluang seseorang untuk mengakses pelayanan kesehatan, memeriksakan diri atau mengambil obat juga dipengaruhi oleh penghasilan termasuk dalam upaya perawatan DM. Perawatan DM yang baik kebanyakan terjadi pada mereka yang pendapatan yang baik dan sebaliknya.

\section{KESIMPULAN}

Kesimpulan penelitian terkait studi komparasi determinan kejadian diabetes mellitus tipe 2 di wilayah perkotaan dan pedesaan Kabupaten Bulukumba adalah terdapat perbedaan konsumsi sugar sweetened beverages, konsumsi makanan cepat saji, aktivitas fisik dan status ekonomi penderita diabetes mellitus tipe 2 di wilayah perkotaan dan pedesaan. Sedangkan tidak terdapat perbedaan perilaku merokok penderita diabetes mellitus tipe 2 di wilayah perkotaan dan pedesaan Kabupaten Bulukumba. Keterbatasan penelitian ini belum mengkaji mengenai riwayat keluarga diabetes, obesitas, tingkat stress, konsumsi buah dan sayur serta konsumsi gula harian. Puskesmas Caile dan Puskesmas Tanete dapat memberikan edukasi faktor risiko seperti pola makan, aktivitas fisik dan perilaku merokok serta komplikasi penyakit diabetes dan melakukan deteksi dini rutin minimal setiap 3 bulan di setiap kelurahan atau desa (Posbindu). Penderita diabetes diharapkan dapat mengurangi konsumsi minuman manis, mengurangi perilaku sedentary, menggunakan gula khusus penderita DM, dan rajin melakukan pemeriksaan gula darah. 


\section{DAFTAR PUSTAKA}

Adri, K., Arsin, A., Thaha, R. M., \& Hardianti, A. (2020). Faktor Risiko Kasus Diabetes Mellitus Tipe 2 dengan Ulkus Diabetik di RSUD Kabupaten Sidrap. Jurnal Kesehatan Masyarakat, 3(1), 101-108. https:// doi.org/10.30597/jkmm.v3i1.10298

Alsabieh, M., Alqahtani, M., Altamimi, A., Albasha, A., Alsulaiman, A., Alkhamshi, A., \& Bashir, S. (2019). Fast food consumption and its associations with heart rate, blood pressure, cognitive function and quality of life. Pilot study. Heliyon, 5(5), e01566. https://doi.org/10.1016/

j.heliyon.2019.e01566

American Diabetes Association. (2019). Classification and diagnosis of diabetes: Standards of Medical Care in Diabetes-2020. Diabetes Care, 43(January), S14-S31. https:// doi.org/10.2337/dc20-S002

Arda, Z. A., Hanapi, S., Paramata, Y., \& Ngobuto, A. R. (2020). Kualitas Hidup Penderita Diabetes Mellitus dan Determinannya di Kabupaten Gorontalo. Jurnal Promotif Preventif, 3(1), 14-21. https://doi.org/10.47650/ jpp.v3i1.145

Azis, W. A., Muriman, L. Y., \& Burhan, S. R. (2020). Hubungan antara Tingkat Pengetahuan dengan Gaya Hidup Pada Penderita Diabetes Melitus. Jurnal Penelitian Perawat Profesional, 2, 105-114. https:// doi.org/10.37287/jppp.v2i1.52

Bâ, H. O., Camara, Y., Menta, I., Sangaré, I., Sidibé, N., Diall, I. B., \& Millogo, G. R. C. (2018). Hypertension and associated factors in rural and urban areas Mali: Data from the step 2013 survey. International journal of hypertension, $2018.2 \mathrm{https} / /$ doi.org/10.1155/2018/6959165

Bhatt, D. L., Szarek, M., Pitt, B., Cannon, C. P., Leiter, L. A., McGuire, D. K., \& Steg, P. G. (2021). Sotagliflozin in patients with diabetes and chronic kidney disease. New England Journal of Medicine, 384(2), 129-139. http://doi.org/10.1056/NEJMoa2030186

Daeli, W. A. C., \& Nurwahyuni, A. (2019). Determinan Sosial Ekonomi Konsumsi Minuman Berpemanis di Indonesia: Analisis Data Susenas 2017. Jurnal Ekonomi Kesehatan Indonesia, 4(1). http://dx.doi.org/10.7454/ eki.v4i1.3066
Hirahatake, K. M., Jacobs Jr, D. R., Shikany, J. M., Jiang, L., Wong, N. D., Steffen, L. M., \& Odegaard, A. O. (2019). Cumulative intake of artificially sweetened and sugarsweetened beverages and risk of incident type 2 diabetes in young adults: the Coronary Artery Risk Development In Young Adults (CARDIA) Study. The American journal of clinical nutrition, 110(3), 733741. https://doi.org/10.1093/ajcn/nqz154

International Diabetes Federation (2019). IDF Diabetes Atlas Ninth edition 2019. https:// www.idf.org/e-library/epidemiologyresearch/diabetes-atlas/159-idf-diabetesatlas-ninth-edition-2019.html

Kapral, M. K., Austin, P. C., Jeyakumar, G., Hall, R., Chu, A., Khan, A. M., ... \& Tu, J. V. (2019). Rural-urban differences in stroke risk factors, incidence, and mortality in people with and without prior stroke: the CANHEART stroke study. Circulation: Cardiovascular Quality and Outcomes, 12(2), e004973. https://doi.org/10.1161/ CIRCOUTCOMES.118.004973

Kementerian Kesehatan RI. (2018). Laporan Hasil Riset Kesehatan Dasar (Riskesdas) Nasional 2017. Jakarta: Badan Litbangkes, Depkes RI.

Lewis, M. T., Lujan, H. L., Wiseman, R. W., \& DiCarlo, S. E. (2019). The hypertension advantage and natural selection: since type 2 diabetes associates with co-morbidities and premature death, why have the genetic variants remained in the human genome?. Medical hypotheses, 129, 109237. https://doi.org/10.1016/j.mehy.2019.109237

Manuntung, A. (2017). Analisis Keyakinan Diri Pasien Diabetes Mellitus Tipe 2 dalam Pengelolaan Diabetes Mellitus. Jurnal Kesehatan Manarang, 3(2006). https:// doi.org/10.33490/jkm.v3i1.32

Nomura, T., Kawae, T., Kataoka, H., \& Ikeda, Y. (2018). Aging, physical activity, and diabetic complications related to loss of muscle strength in patients with type 2 diabetes. Physical therapy research, 21(2), 33-38. https://doi.org/10.1298/ptr.R0002

Oommen, A. M., Abraham, V. J., George, K., \& Jose, V. J. (2016). Prevalence of coronary heart disease in rural and urban Vellore: a repeat cross-sectional survey. Indian heart journal, 68(4), 473-479. https:// 
doi.org/10.1016/j.ihj.2015.11.015

Papier, K., D'Este, C., Bain, C., Banwell, C., Seubsman, S. A., Sleigh, A., \& Jordan, S. (2017). Consumption of sugar-sweetened beverages and type 2 diabetes incidence in Thai adults: results from an 8 -year prospective study. Nutrition \& diabetes, 7(6), e283e283. https://doi.org/10.1038/nutd.2017.27

Pawaskar, M., Witt, E. A., Engel, S. S., Rajpathak, S. N., \& Iglay, K. (2018). Severity of hypoglycaemia and health-related quality of life, work productivity and healthcare costs in patients with type 2 diabetes in Europe. Endocrinology, diabetes \& metabolism, 1(2), e00011. https://doi.org/10.1016/ j.jdiacomp.2018.01.012

Pencina, M. J., Navar, A. M., Wojdyla, D., Sanchez, R. J., Khan, I., Elassal, J., \& Sniderman, A. D. (2019). Quantifying importance of major risk factors for coronary heart disease. Circulation, 139(13), 1603-1611. https://doi.org/10.1161/

CIRCULATIONAHA.117.031855

Pratama, O. W. P., Wutyanto, M. A., \& Ginandjar, P. (2018). Gambaran Kadar Gula Darah Sewaktu pada Penduduk Risiko Tinggi Diabetes Mellitus Tipe 2 Desa Ketawangrejo Kecamatan Grabag Kabupaten Pureorejo. Jurnal Global Health Science, 3(4), 287293. http://jurnal.csdforum.com/index.php/ GHS/article/view/293

Quiñones, A. R., Markwardt, S., \& Botoseneanu, A. (2019). Diabetes-multimorbidity combinations and disability among middle-aged and older adults. Journal of general internal medicine, 34(6), 944-951. https:// doi.org/10.1007/s11606-019-04896-w

Radzeviciene, L., \& Ostrauskas, R. (2018). Smoking habits and type 2 diabetes mellitus in women. Women \& health, 58(8), 884-897. https://

doi.org/10.1080/03630242.2017.1358794

Sundufu, A. J., Bockarie, C. N., \& Jacobsen, K. H. (2017). The prevalence of type 2 diabetes in urban Bo, Sierra Leono, and in the 16 countries of the West Africa region. Journal of Environmental Health, 5(7), 1-17. https:// doi.org/10.1002/dmrr.2904

Tun, N. N., Arunagirinathan, G., Munshi, S. K., \& Pappachan, J. M. (2017). Diabetes mellitus and stroke: a clinical update. World journal of diabetes, 8(6), $235 . \quad \mathrm{https}: / /$ dx.doi.org/10.4239\%2Fwjd.v8.i6.235

Walker, J., Colhoun, H., Livingstone, S., McCrimmon, R., Petrie, J., Sattar, N., \& Wild, S. (2018). Type 2 diabetes, socioeconomic status and life expectancy in Scotland (2012 -2014): a population-based observational study. Diabetologia, 61(1), 108-116. https://doi.org/10.1007/s00125-017-4478-x

World Health Organization. (2019). Classification of diabetes mellitus. In T. Habjouqa, E. Martino, A. Loke, \& F. Naumann (Eds.), Clinics in Laboratory Medicine (Vol. 21, Issue 1). WHO. https://doi.org/10.5005/jp/ books/12855_84

Yosmar, R., Almasdy, D., \& Rahma, F. (2018). Survei Risiko Penyakit Diabetes Melitus Terhadap Masyarakat Kota Padang. Jurnal Sains Farmasi Dan Klinis, 5(2), 134-141. http://dx.doi.org/10.25077/jsfk.5.2.134141.2018 